\title{
Food Supply and Military Mutiny in the Late Roman Empire
}

A.D. Lee

\section{Abstract}

This paper approaches the subject of food supply in late Roman warfare from the perspective of military mutiny, with a view to highlighting the political importance of effective logistics for maintenance of troop loyalty and discipline. It begins by contextualising the subject against earlier periods of Roman history, especially the Republic, when food shortage was an important contributory factor in a number of high-profile cases of military mutiny. Mutiny appears to have been less common during the Principate and the Late Empire, at least until the sixth and early seventh centuries, and when mutiny did occur, food shortage was rarely a factor. While this might seem an anti-climactic conclusion, the paper contends that it provides corroboration of the effectiveness and flexibility of army supply arrangements in the Late Empire. It discusses late Roman evidence for awareness of the dangers of food shortages for soldiers' allegiances and emphasises how the important role of mobile field armies in the Late Empire placed particular pressures on arrangements for military food supply. The apparent lack of military mutinies arising from food shortages during the Late Empire therefore assumes greater significance than might at first seem to be the case. 
Roman military logistics is a subject which, until comparatively recently, received only limited attention. That situation has changed in the last two decades or so, with the publication of a number of important studies on the subject, notably those by Theodor Kissel, Paul Erdkamp and Jonathan Roth. ${ }^{1}$ The chronological focus of these studies has, however, been the Republic and/or the Principate, with the Late Roman Empire suffering comparative neglect, while their emphasis has been on understanding the practicalities of military supply with a view to better explaining Roman military effectiveness and success. Much less explicit attention has been given to the political dimension of the subject-that is, the relevance of logistics to maintaining the loyalty and discipline of troops. Perhaps this has been thought to be so self-evident that it does not warrant discussion, but if so, then it risks underplaying an important aspect of the subject of logistics. The Roman state needed to have effective arrangements in place for supplying its armies not only because this would facilitate its ability to achieve its strategic objectives, but also because failures in supply could easily generate discontent in the ranks which might develop into a refusal to fight or even a willingness to challenge the authority of their commanders. The concern of this paper will therefore be with the relationship between food supply and military mutiny. Its primary focus is the Late Empire, but it is important for its argument to contextualise this

My thanks to Jeroen Wijnendaele and the anonymous reviewer for helpful feedback and suggestions for improvement, and also to Stuart McCunn for many conversations about late Roman logistics.

${ }^{1}$ Kissell 1995; Erdkamp 1998; Roth 1999. For a helpful review of the latter two, see Adams 2001. For a collection of papers with an archaeological focus, see Stallibrass and Thomas 2008. 
against patterns during the Republic and the Principate, so at certain points the paper necessarily ranges back into earlier centuries of Roman history.

Before doing that, however, it is worth registering a number of preliminary observations. First, there is the question of defining mutiny. It has been noted that 'the concept of mutiny appears to be an early modern phenomenon', ${ }^{2}$ and the term was used in some early modern contexts in quite a restricted sense, in which the authorities tended to view it as an acceptable way to air grievances provided the aggrieved did not jeopardise military effectiveness and avoided personal violence. ${ }^{3}$ However, the most detailed discussions of the term in the context of Roman history have argued for a broader definition-in one instance, defining mutiny as "forcible or passive resistance either to a commanding general or to the government of Rome," ${ }^{4}$ and in another as "collective, violent (actual or threatened) opposition to established military authority."

Secondly, recent discussions of military mutiny in earlier periods of Roman history have helpfully proposed envisaging military unrest in terms of a spectrum of possibilities, ranging from soldiers voicing concerns amongst themselves, to their conveying their concerns to the

\footnotetext{
${ }^{2}$ Carney 1996, 20, citing McNeill 1982, 107.

${ }^{3}$ See Rodger 1988, 238 for "the unwritten rules" of mutiny in the Royal Navy of the Georgian period.

${ }^{4}$ Chrissanthos 1997, 172 n.1, with fuller discussion in Chrissanthos 1999, 7-12. A number of the cases which Chrissanthos (1999) discusses involved the lynching of the commanding officer (e.g., 18-19, 50-52, 55-6, 58-9).

${ }^{5}$ Brice 2002, 68.
} 
commander through intermediaries such as centurions or officers, to their communicating directly with the commander in camp meetings, which then gave the commander an opportunity to respond. Often this was sufficient to defuse a situation, but on occasion commanders did not respond with sufficient speed or concessions, and the dissatisfaction of troops could then escalate into open mutiny. ${ }^{6}$ As will be seen below, the Late Empire offers examples of episodes which map onto these various possibilities and serve to validate this approach.

Thirdly, it is also important to highlight the wider significance of the subject of military unrest for how the character of the Roman armed forces is conceived. Despite numerous setbacks in individual battles, the overall record of military success enjoyed by Roman armies in acquiring a Mediterranean-wide empire during the Republic and then maintaining it during the Principate has sometimes tempted some modern writers to describe the Roman army, perhaps without sufficient thought or care, as a "war machine."7 As other commentators have argued, this is an unhelpful way of thinking about the Roman army, not least because it risks implying, no doubt inadvertently, that Roman soldiers were

\footnotetext{
${ }^{6}$ Chrissanthos 2004; Chrissanthos 2013, 323-4.

${ }^{7}$ E.g., Keppie 1984, 169 ("the machinery of the new professional army"); Birley 1988, 5 ("the structure of the machine"); Peddie 1994 ("The Roman War Machine"); Bradley 2004, 308 (“the Roman war machine"); Howarth 2013, 34 ("the Roman military machine"); Harper 2017, 7 ("the war machine"). For use of this phraseology in the context of the Late Empire, see Frank 1969, 79 ("a new military machine"); Williams and Friell 1994, ch.6 ('The War Machine'), McLynn 2005, 102 (“a fighting machine”); Wickham 2005, 102 ("the Roman military machine").
} 
automatons. ${ }^{8}$ The subject of military unrest is another salutary antidote to such ideas, in so far as it gives the lie to the implication of the machine metaphor that Roman troops were so well trained and so disciplined that they never questioned orders or challenged authority.

\section{Food Supply and Military Mutiny in the Republic and Principate}

Turning to the evidence for the relationship between food supply and military mutiny in earlier periods of Roman history, it is necessary, for reasons which will become apparent, to venture back as far as the Republic. Modern discussions vary in their tabulation of mutinies during the Republic. One older study-that of William Messer in 1920-lists about forty instances. More recently, Stefan Chrissanthos has given a figure of sixty. ${ }^{9}$ These variations partly reflect differing definitions of what constitutes mutiny, and partly differing assessments of the historicity of accounts of early Republican history. ${ }^{10}$ There is, however, agreement between these studies, first, that mutiny was a more common phenomenon

\footnotetext{
${ }^{8}$ See the important discussions of Goldsworthy 1996, 283-6 and James 2002 (esp. at 9, 31-
} 2).

${ }^{9}$ Messer 1920; Chrissanthos 2013, 324. The latter does not provide a tabulation of instances, but he must in part be drawing on his unpublished thesis (Chrissanthos 1999). This lists forty-six instances down to $40 \mathrm{BCE}$; since the statement about sixty instances takes Actium as its terminal point, the author has presumably identified a further fourteen cases in the decade between $40 \mathrm{BCE}$ and Actium.

${ }^{10}$ For recent discussion of the evidence for the early Republic in the context of warfare, see Armstrong 2016: 18-46. 
during the Republic than is often acknowledged, and secondly, that there was a particular concentration of instances of mutiny during the first century BCE.

The instance from before the first century BCE about which the most detail is preserved in the ancient sources is the mutiny in 206 BCE during the Hannibalic War by some of Scipio's troops at Sucro in Spain. ${ }^{11}$ Although circumstantial factors such as Scipio falling ill contributed to the outbreak, the underlying causes were four issues which, in varying combinations, often recur in the complaints of soldiers in subsequent episodes-namely: (1) delays in pay; (2) dissatisfaction with the division of booty; (3) length of service; and (4) shortages of supplies. ${ }^{12}$ In his analysis of this episode, Chrissanthos suggests that of these various issues, shortage of supplies may have been the most important factor provoking the mutiny at Sucro: "Scipio's prompt provision of supplies during and after the crisis proves that he realized that fulfilling these needs of the men was vital to his command and the termination of the mutiny."13

As for subsequent mutinies during the Republican period, shortage of supplies, while by no means always a factor, can be seen playing a role in a number of cases. Although difficult winter conditions in eastern Asia Minor were clearly a major cause of the mutiny against Lucullus in 68/67 BCE, the sources imply that food shortages also contributed, along with discontent about the division of booty and unhappiness about the length of service. ${ }^{14}$ The

\footnotetext{
${ }^{11}$ Discussed in detail in Chrissanthos 1997.

12 Polyb. 11.25-30; Livy 28.24-29; App. Hisp. 34-36.

${ }^{13}$ Chrissanthos 1997, 174-5, 182, 183 (quotation on 175).

${ }^{14}$ Plut. Vit. Luc. 32-5; Cass. Dio 36.6.1.
} 
unrest which Caesar had to tackle in 58 BCE at Vesontio in Gaul was attributed (by Caesar) to concerns about food supply, together with fear of an unfamiliar enemy. ${ }^{15} \mathrm{~A}$ further mutiny against Caesar in 49 BCE at Placentia arose from shortages of supplies, alongside length of service, delays in pay and a prohibition on plundering. ${ }^{16}$ Food shortage, then, emerges as a contributory factor in a number of military mutinies during the Republic.

The ways in which commanders responded may also be relevant here. There were instances where punishment was inflicted, at least on those regarded as ringleaders, as Scipio did at Sucro and Caesar at Placentia. However, the predominant pattern was for concessions to be made, even if accounts sometimes try to mask this in their eagerness to defend the reputation of the commander in question. While the avoidance of large-scale punishment was no doubt motivated in part by pragmatic considerations of needing to minimise the loss of manpower, ${ }^{17}$ it may also reflect a tacit recognition that the state bore some responsibility for ensuring that troops were adequately supplied with food.

During the Principate, there is less evidence for soldierly dissatisfaction and mutiny, though instances are not as few as sometimes assumed-one of the main arguments of Lee Brice's 2002 doctoral thesis. ${ }^{18}$ The best known cases are the mutinies among troops in Pannonia and Germany in 14 CE following the death of Augustus, no doubt because Tacitus gave them

${ }^{15}$ Caes. B Gall. 1.39-41. Cf. Cass. Dio 38.35 (who adds concerns about the constitutional legitimacy of Caesar's actions).

${ }^{16}$ Chrissanthos 2001, 67-8.

${ }^{17}$ Chrissanthos 2001, 73-5.

18 Brice 2002. 
particularly detailed attention in Book 1 of his Annals. ${ }^{19}$ The chief grievances here were length of service and level of pay, together with complaints about overly harsh discipline. This discontent with conditions of service continues one of the themes from the Republic, but it was not an issue which persisted beyond the early stages of the Principate. Augustus' establishment of a standing army with regular pay, fixed terms of service and generous discharge bonuses must have helped to deal with what had been one of the main causes of mutiny during the Republic, even if the full impact of these measures had not yet been sufficiently felt by the end of his reign to prevent the mutinies of $14 \mathrm{CE}$. Indeed it has been suggested that the discontent spilled over in that year because men were being retained in the ranks long beyond the official maximum for service due to the money not being available to pay their discharge bonuses-a problem which appears to have been resolved with the passage of time. ${ }^{20}$

Of more immediate relevance to the concerns of this paper, there is little, if any, evidence for supply problems generating military unrest during the Principate. This is a development which can be related most obviously to another aspect of Augustus' changes to the militarynamely, his stationing of military units in bases adjacent to the empire's frontiers. While these may initially have been envisaged as temporary bases in anticipation of further advances of the frontiers, many of them soon became permanent. ${ }^{21}$ This marks an important change from the Republic, when armies were typically deployed on offensive campaigns and needed to be much more mobile-a pattern which presented greater

19 Tac. Ann. 1.16-44.

${ }^{20}$ Dobson 1986, 14.

${ }^{21}$ Keppie 1984, 191-7. 
challenges in terms of logistical organisation and support. The emergence of permanent bases during the Principate introduced a greater degree of certainty into logistical requirements and arrangements, so long as forces were operating out of these bases, thereby greatly reducing the likelihood of food shortages. The mounting of major campaigns such as Trajan's Dacian wars will of course have placed additional pressures on supply arrangements, but although literary sources for military operations in the second century are less detailed, there do not appear to be any instances from the Principate where supply problems were sufficiently serious to result in military unrest.

\section{Food Supply and Military Mutiny in the Late Roman Empire: The Evidence}

Turning to the early stages of the Late Empire, rebellious soldiers are often seen as a common feature of the empire's upheavals in the mid third century, ${ }^{22}$ but it is difficult to identify episodes which can be classed as "bottom-up" mutiny emerging from ranks rather than civil war arising from attempted "top-down" usurpation, even taking into account the limitations of the sources for this period. There were certainly instances when troops killed the emperor, but almost invariably this was in the context of confronting a rival challenger for the throne, with whom, for whatever reason, the troops had decided to throw in their lot. One episode which is closer to Republican precedents and is relevant to the issue of food supply is the mutiny against Maximinus Thrax at Aquileia in 238. Although this occurred during the civil war between Maximinus and the senate, it warrants consideration in the context of military mutiny because it was an episode in which food shortages seem to have played a critical role in turning the troops against Maximinus, rather than their making

${ }^{22}$ E.g., Alföldy 1974, 99-100; Potter 1990, 41. 
a political calculation to throw their lot in with an alternative emperor. The context was Maximinus' attempt to capture Aquileia by siege, so that one might have thought that it would be the inhabitants of the city who were most likely to experience hunger. However, Maximinus had left Sirmium for Italy in such a hurry that the usual advance planning of supplies had not been undertaken and en route the inhabitants of the major centre of Emona had destroyed any supplies they could not carry before abandoning the city. ${ }^{23}$ When Maximinus and his army reached Aquileia,

the people of Aquileia had no shortage of anything, but were well supplied because of their careful preparation in building up stocks in the city of all the provisions needed to feed and water men and beasts. The army, on the other hand, was suffering from a shortage of everything because the fruit trees had been cut down and the countryside devastated by themselves. Some of them were under improvised shelters, but the majority were out in the open air, enduring the rigours of rain and sun, and dying of hunger because of the breakdown in supplies of even the imported food for themselves

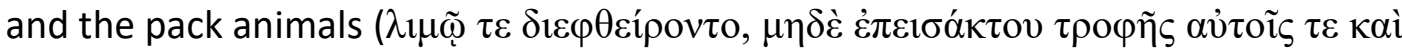

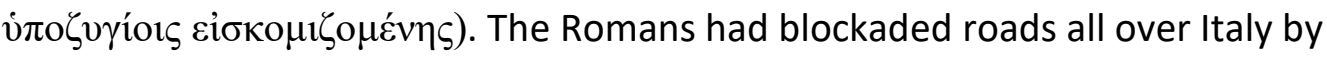
constructing barriers and operating gate controls... As a result of Roman action the soldiers were in a desperate position, short of everything... These were the prevailing

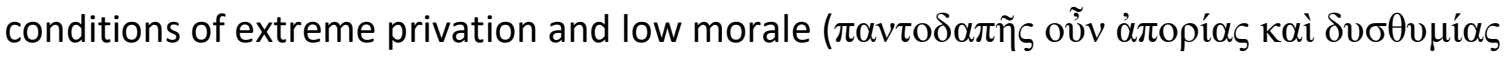

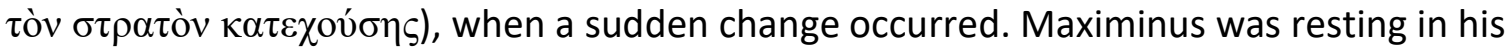
quarters, and there was a break in the fighting that day... Suddenly the soldiers from the camp on Mount Alba...decided to murder Maximinus, so that they could abandon the

\footnotetext{
${ }^{23}$ Herodian 7.8.10-11, 8.1.4-5.
} 
long, interminable siege, and stop laying waste Italy for the benefit of a tyrant who was condemned and hated. ${ }^{24}$

Here, then, is a case from very early in the Late Empire, as usually defined, where food shortage precipitated mutiny. The soldiers refused to continue to fight, with some deciding that the only way to guarantee a cessation was to eliminate their commander. However, two important qualifications need to be registered. First, it occurred in the specific context of a siege, and siege warfare placed particular demands on logistical arrangements, not just for the besieged, but also for the besiegers. This was one of the reasons, after all, why northern barbarians were usually unable to sustain sieges of Roman cities. ${ }^{25}$ The second qualification is a more general one-namely, that this is one of very few instances of mutiny of any sort during the Late Empire prior to the sixth century.

To be sure, there is interesting evidence from the fourth century indicating awareness of the potential for delays in the supply of food to generate unrest among troops. In the first of his two panegyrics honouring the emperor Constantius II in the 350s, his cousin Julian describes the emperor's preparations for a campaign against the Persians. Among other things, he noted that "the war called for money, provisions and supplies on a vast scale... The troops

\footnotetext{
${ }^{24}$ Herodian 8.5.3-8 (tr. C. R. Whittaker).

${ }^{25}$ Elton 1996, 84-5. Barbarian siege capability improved over the fifth century, notably on the part of the Huns (though more through exploiting Roman prisoners of war with relevant skills in siege technology than better logistical arrangements) (Petersen 2013, 46-8, 365-8), but as early as $430 / 431$ the Vandals proved able to sustain the siege of north African Hippo for fourteen months, even if eventually forced to abandon it (Wijnendaele 2015, 92-6).
} 
under your leadership were abundantly supplied, yet not so as to cause the surfeit that leads to insolence, nor, on the other hand, were they driven to insubordination from lack of necessities." ${ }^{26}$ Likewise, in his second panegyric to the same emperor, Julian makes a similar point when describing the qualities of the ideal ruler. "He must plan as well...so that [the troops] have abundant provisions and run short of none of the necessities of life. For often the most loyal guardians and protectors of the flock are driven by want to become fierce towards the shepherds, and when they see them from afar they bark at them and do not even spare the sheep." 27 It was recognised, then, that shortage of supplies could precipitate unrest and also prompt military violence against civilians-and hence effective organisation of food supply was a priority.

Constantius himself had direct experience of the potential for problems with the food supply to generate unrest among his troops when he began a campaign against the Alamanni in Gaul in 354. He found that he had to delay the start of the campaign because he was waiting for supplies to be transported from Aquitania and their progress was delayed by unusually heavy spring rains, sufficient to cause the flooding of rivers. As Ammianus Marcellinus proceeds to explain,

the troops who were assembled at Châlons chafed at the delay, all the more because they lacked even the necessities of life (subsidia vivendi), because their usual supplies (alimenta) had not yet arrived. This brought Rufinus, at that time praetorian prefect, into great danger. To pacify the army and explain the reason why the supplies (annona) were

\footnotetext{
${ }^{26}$ Jul. Or. 1.21b, 22a (tr. W. C. Wright). For discussion of this speech, see Tougher 2012.

27 Jul. Or. 2.88ab (tr. W. C. Wright). For discussion of this speech, see Drake 2012.
} 
held up, he was obliged to go in person to visit the troops, whose surliness was increased by the shortage of food (inopia) and who in any case were traditionally rough and brutal in their behaviour to civil functionaries. ${ }^{28}$

In the event, he was able to forestall any more serious problems by secretly distributing money to those who were encouraging the unrest, and then shortly afterwards "supplies arrived in abundance." ${ }^{29}$ Here, then, was an instance illustrating the real potential for food shortages to create unrest which might easily have escalated into outright mutiny. It is worth noting, however, that the problem arose not because of a lack of planning, but rather because that planning was disrupted by unusual weather conditions.

In a similar vein, a few years later Julian, as Caesar in the west, found himself facing abuse from his troops in northern Gaul after his forces ran out of food while on campaign. Julian had overseen the rebuilding of three forts on the River Meuse and had restocked them with food out of his men's rations, thinking that he would be able to make up the difference from the harvests of neighbouring tribes-only to find that their crops were not yet ripe. ${ }^{30}$ This may have been another instance of adverse weather conditions delaying the harvest and disrupting plans.

Other instances of mutiny or near-mutiny before the sixth century, whether related to food supply or not, are few and far between, although the sources for the fifth century are generally less detailed than those for the fourth and sixth centuries. There is a brief report

${ }^{28}$ Amm. 14.10.3-4 (tr. W. Hamilton, with revisions).

${ }^{29}$ Amm. 14.10.5.

${ }^{30}$ Amm. 17.9. 
of soldiers in the eastern provinces stirring up an insurrection against their commander Maximinus and killing him in $420,{ }^{31}$ but nothing further is known about this episode or the victim. There is another report of soldiers, probably in the $470 \mathrm{~s}$, being deprived of supplies and pay which may have resulted in a mutiny-but the report is so brief and lacking in context that it is difficult to draw any wider conclusions. ${ }^{32}$ And the emperor Zeno's decision in 478 not to proceed with a campaign against the Goths prompted the troops to gather in groups and criticise the emperor, with the possibility of a mutiny developing had they not agreed to disperse to their winter quarters. ${ }^{33}$ Food shortage does not appear to have played any part in this, with the most likely explanation being soldiers' unhappiness at being deprived of an opportunity for booty. ${ }^{34}$

While the most obvious instances of mutiny in the sixth century occurred during the reign of Justinian, there is an episode from the reign of Anastasius to consider first-namely, the revolt of Vitalian in $513 .{ }^{35}$ John of Antioch provides the most detailed account of the background:

\footnotetext{
${ }^{31}$ Marcell. com. s.a. 420.

${ }^{32}$ Malch. fr. 27 (Blockley).

${ }^{33}$ Malch. fr. 18.3 (Blockley).

${ }^{34}$ Although Julian's proclamation as emperor by his troops at Paris in 360 is sometimes regarded as a case of military mutiny, there is good reason to regard this as a case of usurpation in which Julian and/or his close allies exploited the discontent of soldiers to their own ends: see Bowersock 1978, 46-52; Tougher 2007, 36-41.

35 For overviews, see Haarer 2006, 164-79; Meier 2009, 295-311; Sarantis 2016, 129-35.
} 
At this time the region of Thrace was thrown into utter confusion by Vitalian...; he was the son of Patriciolus from Zaldaba, an obscure town in Lower Moesia. Since he had spent much time among the Huns, it was reported to the emperor that he was becoming more inclined towards rebellion. After he had been deprived of the state rations known

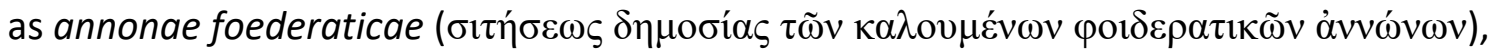
he put forward a plan to the men of the units stationed in Scythia and Thrace, who were already annoyed on their own account at the abuse they had been suffering from their magister Hypatius, and so he easily convinced them to set about this utterly unlawful venture. ${ }^{36}$

From these beginnings, Vitalian was able to mount a very serious challenge to Anastasius, twice coming close to capturing Constantinople and forcing the emperor to agree to a reconsideration of his religious policy, even if ultimately unsuccessful. The point of interest from the perspective of this paper is obviously the reference to troops being deprived of their state rations and this contributing to their willingness to support Vitalian. On reflection, however, this is less relevant than it might at first appear. Rather than being a case of the supply arrangements not operating properly, this seems to be a case of the central authorities deliberately curtailing the provisions for his troops as a strategy for undermining the authority of an officer whose loyalties were suspect. If the expectation was that this would provoke his troops against Vitalian, then his enemies had clearly miscalculated.

${ }^{36}$ Joh. Ant. fr. 242 (tr. S. Mariev). 
As already noted, it is during the reign of Justinian that there occurs the first serious mutiny since the third century. This mutiny began in 536 among the troops who had been involved in the campaign to recover north Africa from the Vandals and who then remained there as the garrison. ${ }^{37}$ Delay in the payment of troops features as a contributory factor, but other factors do not have obvious comparanda from the Republic. First, there was the decision of the imperial government to return land seized by the Vandals in the fifth century to the descendants of its previous owners. This caused dissatisfaction because many of the imperial troops had taken up with Vandal women who stood to lose from this decision. Secondly, there was the imperial government's ban on the holding of church services in accord with the heterodox Arian liturgy. Although this was directed at the residual Vandal population, some of the imperial troops who had been recruited from barbarian groups were also Arian in their allegiance, and this affected them as well. ${ }^{38}$ This mutiny, led by an officer named Stotzas, continued on and off for nearly a decade, with the authorities using a combination of concessions and force to try to terminate it. However, food supply was not a direct issue in this case.

Following the suppression of this major mutiny after nearly a decade, in 545 , there were some further episodes of unrest among troops in north Africa, but these too were associated with delays in soldiers receiving their pay. ${ }^{39}$ Delay in pay was also a major factor in an instance of mutiny in Italy in 544, when units of soldiers from Illyria withdrew from Bologna in order to return home. These troops actually sent envoys to the emperor in

37 Kaegi 1965; Kaegi 1981, 41-63.

${ }^{38}$ Proc. BV 2.14.7-21 (land and religion); 2.15.55 (delayed pay).

39 Proc. BV 2.18.9, 2.26.10; BG 3.11.13-16, 3.12.7-8. 
Constantinople to explain their conduct, citing by way of excuse their long service in Italy and lack of regular pay, though Procopius also says that scarcity of provisions was a further factor in their decision. ${ }^{40}$ These delays in pay were largely a result of the multiple military commitments which the Roman state faced in this period, both in north Africa and further afield, but apart from this last instance from Italy, food supply does not appear to have been a contributory factor.

One episode from Justinian's reign where food supply does seem to have impinged more directly was when an imperial army confronted a body of Slavs near Adrianople in early 551. There was what Procopius describes as a "prolonged" stand-off between the two forces, and although the length of time involved is not specified, it must have been substantial, involving at least a good number of days, since "the soldiers began to lose their patience and take it badly, accusing the generals that while they themselves, as officers of the Roman army, were well supplied, they were overlooking the soldiers, who were being hard-pressed by a lack of necessities." 41 If the Roman officers' strategy was, as seems likely, one of playing a long game and trying to wear down the Slavs to the point where they surrendered, then it looks like they had not planned their own logistics sufficiently to support the strategy. In the event, the soldiers' discontent did not escalate into outright mutiny, because the officers' response to their accusations was to engage in battle with the Slavs-a battle in which the Roman forces suffered a decisive defeat. Whether that defeat was due in part to the troops being weakened by hunger is not made clear by Procopius, but it seems a distinct possibility.

\footnotetext{
40 Proc. $B G$ 3.11.13-16.

${ }^{41}$ Proc. BG 3.40.39 (tr. H. B. Dewing).
} 
Pay-related issues continued to be a cause of military unrest during the reigns of Justinian's successors. The first such episode involved the army in Armenia where, in 579, a large number of troops refused to fight until they received their pay in full. The emperor Tiberius II's response was to despatch a senior court official with sufficient gold to appease the men, who then agreed to resume their duties. ${ }^{42}$ In 588 , news of a reduction in pay by a quarter and a change in the length of service (presumably to longer) precipitated a mutiny in northern Mesopotamia which lasted for twelve months until a local bishop, Gregory of Antioch, successfully mediated. The troops were granted an amnesty and it looks like the proposed changes to conditions of service were not implemented. ${ }^{43}$ In neither instance is there any reference to shortages of food contributing to the soldiers' discontent.

The most serious mutiny of the half century after Justinian's reign involved the Danube army in 602, which eventually resulted in the overthrow of the emperor Maurice and an extended period of very damaging upheaval for the empire. This episode did not emerge without any forewarning, for the Danube army had shown mutinous tendencies during the mid-590s, arising from issues all too familiar from as far back as the Republic. ${ }^{44}$ In 593 the troops threatened to mutiny when they learned that all the booty from recent campaigning north of the Danube was to be sent to the emperor and his family in Constantinople, with none of it being distributed to the troops; it was only a persuasive address by their commander Priscus which induced them to accept this decision. However, when it was then

\footnotetext{
42 Evagr. HE 6.28.

${ }^{43}$ Theoph. Sim. 3.1-3; Evagr. HE 6.4, 11-13; further discussion in Kaegi 1981, 68-72; Whitby 1988, 286-9; Lee 2007b, 99-100.

${ }^{44}$ Theoph. Sim. 6.7-8, 10.1-3; 7.1.
} 
announced that they were to winter north of the Danube, there was renewed unrest which induced Priscus to accede to their demand that they return south of the river. The following year, the emperor planned to introduce a major change to the way in which soldiers were paid, whereby, instead of receiving all their pay in money, they would now receive twothirds in the form of clothing and equipment. When advance news of this leaked to troops in the Danube army and it became clear that they were again on the verge of mutiny, their commander Peter decided not to proceed with this and instead announced some other, more favourable changes to their conditions of service. However, during these episodes of unrest in the 590s, there is never any suggestion that food shortages contributed to soldiers' dissatisfaction.

The mutiny of 602 itself was precipitated by Maurice's renewed insistence that the Danube army winter north of the Danube in order to combat the threat from Slavic raiders. ${ }^{45}$ While there appear to have been good strategic reasons for this approach-it was easier to avoid Slav ambushes and bring them to battle when the forests were bare and the rivers frozenthe soldiers were unhappy about having to campaign in difficult and inhospitable conditions, much as Lucullus' troops had been in Asia Minor in 68 BCE. Echoing other familiar issues, there were also concerns in 602 about booty and about pay, and there may also have been a food supply aspect. At any rate, one source commented that "the emperor insisted to [the general] Peter by courier that he lead the forces across the river [Danube] and attack the land of the barbarians, and that the Romans derive from there the provisions for the camp,

\footnotetext{
45 Theoph. Sim. 8.6, 10; cf. John of Nikiu 102.10; further discussion in Kaegi 1981, ch.5; Whitby $1988,165-9$.
} 
and thereby provide for the treasury an interruption of public maintenance. ${ }^{\prime 46}$ In other words, it appears that part of the rationale for Maurice's decision was to economise on supplying food to the army by requiring troops to live off enemy land. If so, then one can understand the soldiers' discontent, given that there will have been no produce in the fields during the winter months and so troops will have faced the additional challenges of locating and then seizing enemy stores.

As soldiers had often done in the past, these troops initially communicated their concerns to their commander Peter through representatives. At one stage in negotiations, the troops seemed on the point of relenting and began constructing vessels to cross the river northwards, until the sudden onset of winter weather changed their minds. ${ }^{47}$ Whereas Priscus had realised in 593 that it was unwise to persist in requiring the men to winter north of the Danube, in 602 the general Peter refused to make any concessions, reflecting the attitude of Maurice in Constantinople, with whom Peter was in communication about the situation. ${ }^{48}$ Unlike Scipio at Sucro and Caesar at Placentia, however, Peter did not act decisively against the ringleaders of the mutiny, which proved a fatal error. In this particular case, it was especially unwise not to take heed of the soldiers' concerns, or alternatively not to take decisive action against their leaders, because of the relative geographical proximity of the troops to the imperial capital-in contrast with the north African mutiny of 536, or going much further back in time, the mutinies of the Pannonian and Rhine legions in $14 \mathrm{CE}$ which were never likely to pose a direct threat to the emperor's position because of the

\footnotetext{
${ }^{46}$ Theoph. Sim. 8.6.10 (tr. M. Whitby and M. Whitby).

47 Joh. Nik. 102.10; Theoph. Sim. 8.6.7-9.

${ }^{48}$ Theoph. Sim. 8.6.10-8.7.6.
} 
physical remove involved. ${ }^{49}$ In 602 , however, the troops soon organised themselves to march on the imperial palace in Constantinople where they proceeded to overthrow Maurice and replace him with one of their officers, Phocas, with disastrous consequences for the empire..$^{50}$

What, then, emerges from this survey of military mutiny during the Late Roman Empire, from contextualising it against earlier periods of Roman history, and from considering the relationship between food supply and mutiny? First, it appears that military mutiny was not a constant throughout Roman history. The surviving sources do not provide the same level of detail across all periods, but what is available indicates that mutinies occurred most frequently during the Republic, dipped significantly during the Principate, and remained infrequent during the Late Empire, until there was something of a resurgence during the sixth and early seventh century. Secondly, the impact of the most common causes of mutiny during the Republic-delays in pay, dissatisfaction with the division of booty, length of service, and shortages of supplies-is likely to have been intensified by the fact that Republican forces were not standing armies, but comprising conscripted citizens with other

\footnotetext{
${ }^{49}$ The emperor Tiberius is said by Tacitus (Ann. 1.47) to have regarded the Pannonian legions as a potential threat to Italy, but it suited Tacitus' agenda to maximise the danger to Tiberius (Wiedemann 1996, 207-8) and these units were based much further away from Rome than Maurice's troops on the lower Danube were from Constantinople (by one estimate (Brice 2002, 166), the Pannonia legions would have required almost a month's marching to reach Rome).
}

50 Olster 1993; Kaegi 2003, 37-40. 
obligations to consider. The fact that the frequency of mutinies dipped during the Principate must surely reflect the gradual impact of Augustus' changes to army service (after the early wobble in 14 CE) and, most importantly for the subject of food supply, the stationing of troops in what quickly became permanent bases near the frontiers, which introduced a much greater level of certainty and predictability into military supply.

Turning to the Late Empire, what is striking is the almost complete absence of military mutiny by the rank-and-file (as distinct from commander-led usurpations) prior to the sixth century. It is tempting to regard this as simply a continuation of the pattern from the Principate-in other words, because soldiers continued to have defined pay and periods of service, some of the central factors which had prompted mutiny during the Republic continued to be largely irrelevant. Yet one of the features noted above under the Principate did not remain entirely constant-namely, troops being stationed in permanent bases. This certainly applied to one major category of soldier, the limitanei who were based in forts in frontier provinces. ${ }^{51}$ However, one of the distinctive features of late Roman military organisation was the emergence of mobile field armies as a significant proportion of the empire's military manpower, and although they were not in a state of perpetual motion, their regular movements nonetheless posed renewed logistical challenges of an order and regularity which the Principate had faced much less frequently.

This is particularly relevant to the point that, unlike the Republic when food supply was a factor contributing to the incidence of mutinies, the Late Empire, at least before the sixth century, saw very little in the way of military mutiny. It is the proposal of this paper that the

${ }^{51}$ For this category of soldier, see Isaac 1988, 139-47; Whitby 1995, 111-14. 
virtual absence of food-shortage-inspired mutiny in the Late Empire prior to the sixth century indicates something important about the effectiveness of the measures for army supply which emerged during the late third and early fourth centuries ${ }^{52}$-in other words, that if there was little if any military discontent arising from food shortages, even in a situation involving the increased challenges of supplying mobile field armies, then the mechanisms developed for supplying armies in the Late Empire must generally have been working well.

If that was the case, then what about the sixth and early seventh century, when the incidence of mutiny once more increased? As already noted, the most frequent cause of mutiny in the latter stages of the Late Empire was delays in pay, ${ }^{53}$ and that surely reflects partly the fact that from Justinian's reign onwards the empire was fighting wars on multiple fronts, with corresponding financial pressures, and partly the fact that those campaigns ranged across a much wider geographical spread than the empire had had to deal with for a considerable period of time. Although food supply was not such a regular factor in mutinies as delays in pay, it sometimes featured, and this might also be explained in terms of the ambitious geographical range of Justinian's campaigns placing additional stresses on supply mechanisms.

52 For which see Jones 1964, 448-62, 626-30; Lee 2007a, 85-7; McCunn 2018, chaps 1-3.

${ }^{53}$ One might reasonably expect this also to have been a problem in the mid fifth century west, as increasing losses of territory progressively reduced the western government's tax income. Troops on the Danube frontier in Noricum went unpaid in the 470 s, though without mutiny (Eugipp. V. Sev. 20). 


\section{Late Roman Logistical Capability}

It must be acknowledged that the main argument here is one that relies to some extent on silence-that is, the relative silence of the sources about military mutinies during the Late Empire prior to the sixth century. In view of this, it is important to supplement the argument from silence with a reminder of some examples of positive evidence for the capabilities of the late Roman supply system to gather and distribute substantial quantities of foodstuffs for military campaigns, familiar though these instances may be. ${ }^{54}$

First, there is the testimony of Julian, in his Letter to the Athenians. In the course of his account of his efforts to re-establish Roman authority in northern Gaul, he refers to a fleet of 600 ships from Britain advancing up the Rhine-ships which are known from another source to have been carrying grain to restock granaries in frontier forts as far upstream as Bingen. Although the size of the ships is not specified, and must have been constrained to some extent by the depth of the river which will have been shallower than in modern times, the number of vessels nonetheless provides an impressive index of Roman logistical capability in the mid-fourth century. ${ }^{55}$ Even more impressive are the figures which Julian provides later in the same text concerning Constantius' logistical preparations for his military confrontation with Julian in 361 , following the latter's unauthorised acclamation as

\footnotetext{
${ }^{54}$ This evidence is complemented by the recognition in late Roman military treatises of the importance of effective military supply, even if they do not explicitly associate it with reducing the likelihood of military discontent: Veg. Mil. 3.3; Maurice Strat. 8.1.30, 8.2.24. ${ }^{55}$ Jul. Ep. ad Ath. 280a, with Amm. 18.2.3-4. For the depth of Rhine in the Late Empire, see Lee 1993, 97, Franconi 2017.
} 
emperor the previous year: "On the frontiers of Gaul in the cities nearby he ordered to be got ready three million medimnoi of wheat which had been ground at Brigantia, and the same amount near the Cottian Alps." ${ }^{56}$ Even allowing for the tendentious nature of this text, ${ }^{57}$ there can be no denying the significance of these quantities for late Roman logistical effectiveness.

Secondly, there is the testimony of Zosimus (presumably reflecting that of his source, Eunapius) concerning Valen' preparations for his first Gothic war in 367: “He appointed Auxonius praetorian prefect....and he conveyed the soldiers' provisions on a large fleet of transports through the Black Sea to the mouths of the Danube, and thence by means of river boats stored them in the towns along the river to facilitate the supply of the army." ${ }^{58}$ No quantities are mentioned on this occasion, but a clear impression is given of careful and timely organisation of supply on a major scale. As with Julian's shipping of grain from Britain to Gaul via the Rhine, so also here, significant quantities of provisions were transported over considerable distances, since although the origin of the provisions is not indicated in this

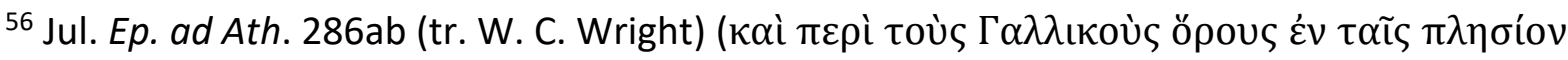

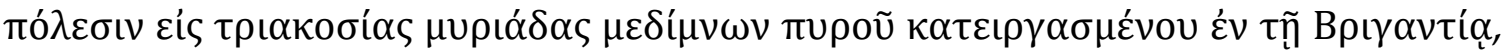

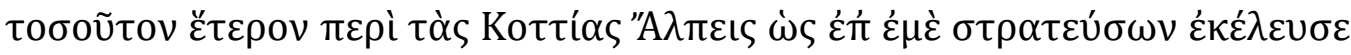
$\pi \alpha \rho \alpha \sigma \kappa \varepsilon v \alpha \sigma \theta \tilde{\eta} v \alpha \iota)$

${ }^{57}$ Humphries 2012.

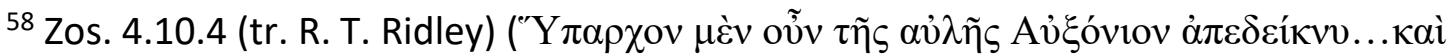

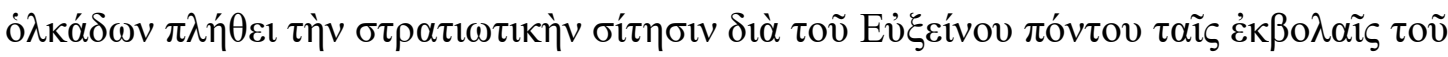

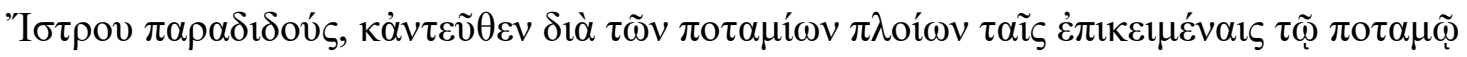

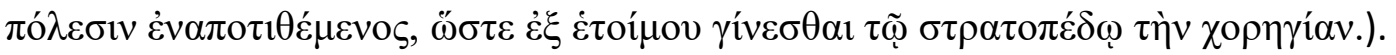


case, their waterborne conveyance through the Black Sea shows that they came from outside of the Balkans.

Finally, there is the contemporary Chronicle attributed to Joshua the Stylite from the early years of the sixth century, which includes much detail about the empire's war with Persia in northern Mesopotamia during the reign of the emperor Anastasius. ${ }^{59}$ In particular the author refers to the inhabitants of Edessa baking 630,000 modii of grain on one occasion in order to feed the imperial army stationed there, and 850,000 modii of grain on another occasion. ${ }^{60}$ In this latter instance, the author also refers to an official, Apion, being sent to Egypt to organise the baking of longer-lasting bucellatum ("twice-baked" bread) for despatch to the troops in Mesopotamia, again illustrating the ability of the state's administrative infrastructure to co-ordinate the movement of substantial quantities of foodstuff from one part of the empire to another. ${ }^{61}$

These episodes at Edessa are also noteworthy for the way in which the organisation of the grain supply and baking was overseen by a specially appointed deputy praetorian prefect (initially Apion, and then Calliopius). Although there was a mid-fifth century precedent for this post, it was an office which was increasingly used for this purpose during the sixth century and which can be seen as testimony to the flexibility of the late Roman state's

${ }^{59}$ For an overview of the war, see Greatrex 1998, 73-118.

60 Ps.-Josh. Styl. 54, 70.

${ }^{61}$ Apion was from a prominent family of landowners in Egypt, whose experience in overseeing the running of an extensive and complex estate (for which see Sarris 2006, chs 12; cf. also Hickey 2012) must surely have informed his contribution to military logistics. 
logistical arrangements in a period when the empire was more proactive in initiating major campaigns. $^{62}$

The establishment of the quaestura exercitūs in the 530s can be viewed in a similar way. This arrangement brought the lower Danube provinces of Moesia and Scythia under the authority of a newly-created official who also had oversight of the geographically distant provinces of Caria, Cyprus and the Cyclades. Although its purpose has been the subject of some debate, the most plausible rationale for this unusual configuration is that the latter provinces, with their relative agricultural prosperity and ready supply of shipping, were providing logistical support to military units based in the lower Danube provinces, whose agricultural output had been handicapped by persistent exposure to frontier warfareproviding another example of the late Roman state's ability to transfer significant food resources from one part of the empire to another in order to facilitate its military objectives. $^{63}$

62 Scharf 1991, with fuller treatment in McCunn 2018, ch.4.

${ }^{63}$ Lee 2007a, 109-11; Sarantis 2016, 143-9; Deligiannakis 2016, 89 (including reference to archaeological evidence for the economic prosperity of the three Mediterranean provinces in the sixth century); McCunn 2018, ch.4. For the archaeology of late Roman granaries in the Balkans, see Rizos 2013. For fourth- and fifth-century anticipations of this pattern, see the epigraphic evidence from the lower Danube forts at Oescus and Novae (dedications by military officers from the Aegean after transporting supplies): Bresson et al. 1995, 141-2; Sarnowski 2005; cf. also Łajtar 2015 and Rizos 2015, 298-300. 


\section{Conclusion}

The aim of this paper has been to approach the subject of military food supply in the Late Roman Empire from the rather different perspective of military mutiny. The outcome of this investigation has been that there is, by and large, an absence of evidence for food shortages as a factor in military mutiny in this period - a potentially anticlimactic conclusion, which also runs the risk of being dismissed as one which relies significantly on the near silence of the sources. However, by contextualising this near silence against the wider chronological background of military mutiny during the Principate and especially the Republic, it becomes a silence pregnant with significance. The fact that the historians Ammianus Marcellinus, Procopius, Agathias, and Theophylact Simocatta provide detailed narratives of substantial portions of the fourth and sixth centuries, with a special focus on the military, further strengthens the significance of this silence. Particularly when placed alongside some of the evidence for the logistical capability of the late Roman state, this near silence lends credence to the proposal that the relative absence of evidence for military mutiny inspired by food shortages during the Late Empire actually reflects and corroborates the broad effectiveness of late Roman logistical arrangements.

\section{References}

Adams, Colin. 2001. "Holding the wolf by the ears: Logistics and the Roman army." Journal of Roman Archaeology 14: 465-72.

Alföldy, Geza. 1974. "The crisis of the third century as seen by contemporaries." Greek, Roman and Byzantine Studies 15: 89-111. 
Armstrong, Jeremy. 2016. War and Society in Early Rome: From Warlords to Generals.

Cambridge: Cambridge University Press.

Birley, Eric. 1988. The Roman Army: Papers 1929-1986. Amsterdam: J.C. Gieben.

Bowersock, Glen W. 1978. Julian the Apostate. London: Duckworth.

Bradley, Keith. 2004. “On captives under the Principate.” Phoenix 58: 298-318.

Bresson, Alain, Drew-Bear, Thomas, and Zuckerman, Constantin. 1995. "Une dédicace de primipilaires à Novae pour la victoire impériale." Antiquité tardive 3: 139-46.

Brice, Lee L. 2002. "Holding a Wolf by the Ears: Mutiny and Unrest in the Roman Military 44 BC-AD 68." Unpublished PhD thesis, University of North Carolina at Chapel Hill.

Carney, Elizabeth. 1996 "The Macedonians and mutiny." Classical Philology 91: 19-44.

Chrissanthos, Stefan G. 1997. "Scipio and the mutiny at Sucro, 206 BC." Historia 46: 172-84.

Chrissanthos, Stefan G. 1999. "Seditio: Mutiny in the Roman Army, 90-40 BC." Unpublished PhD thesis, University of Southern California.

Chrissanthos, Stefan G. 2001. "Caesar and the mutiny of 47 BC." Journal of Roman Studies 91: 63-75.

Chrissanthos, Stefan G. 2004. "Freedom of speech and the Roman republican army." In Free Speech in Classical Antiquity, edited by I. Sluiter and R. Rosen, 341-67. Leiden: Brill.

Chrissanthos, Stefan G. 2013. "Keeping military discipline." In The Oxford Handbook of Warfare in the Classical World, edited by Brian Campbell and Lawrence A. Tritle, 312-29. Oxford and New York: Oxford University Press.

Deligiannakis, Georgios. 2016. The Dodecanese and the Eastern Aegean Islands in Late Antiquity, AD 300-700. Oxford: Oxford University Press. 
Dobson, Brian. 1986. “The Roman army: wartime or peacetime army?” In Heer und Integrationspolitik: Die römische Militärdiplome als historische Quelle, edited by Werner Eck and Hartmut Wolff, 10-25. Cologne: Böhlau.

Drake, Hal. 2012. “'But I digress...': Rhetoric and propaganda in Julian's second oration to Constantius." In Emperor and Author: The Writings of Julian the Apostate, edited by Nicholas Baker-Brian and Shaun Tougher, 35-46. Swansea: Classical Press of Wales.

Elton, Hugh. 1996. Warfare in Roman Europe, AD 350-425. Oxford: Clarendon Press.

Erdkamp, Paul. 1998. Hunger and the Sword: Warfare and Food Supply in Roman Republican Wars (264-30 BC). Amsterdam: J. C. Gieben.

Franconi, Tyler V. 2017. “Pater Rhenus: The hydrological history of Rome's German frontier." In Fluvial Landscapes in the Roman World, edited by Tyler V. Franconi, 85-96. Portsmouth, RI: JRA Supplementary Series 104.

Frank, R.I. 1969. Scholae Palatinae: The Palace Guards of the Later Roman Empire. Rome: American Academy.

Goldsworthy, Adrian. 1996. The Roman Army at War, 100 BC-AD 200. Oxford: Clarendon Press.

Greatrex, Geoffrey. 1998. Rome and Persia at War, 502-532. Leeds: Francis Cairns.

Haarer, Fiona K. 2006. Anastasius I: Politics and Empire in the Late Roman World. Cambridge: Francis Cairns.

Harper, Kyle. 2017. The Fate of Rome: Climate, Disease and the End of Empire. Princeton: Princeton University Press. 
Hickey, Todd M. 2012. Wine, Wealth and the State in Late Antique Egypt: The House of Apion at Oxyrhynchus. Ann Arbor: University of Michigan Press.

Howarth, Randall S. 2013. "War and warfare in ancient Rome." In The Oxford Handbook of Warfare in the Classical World, edited by Brian Campbell and Lawrence A. Tritle, 29-45. Oxford and New York: Oxford University Press.

Humphries, Mark. 2012. “The tyrant's mask? Images of good and bad rule in Julian's Letter to the Athenians." In Emperor and Author: The Writings of Julian the Apostate, edited by Nicholas Baker-Brian and Shaun Tougher, 75-90. Swansea: Classical Press of Wales.

Isaac, Benjamin. 1988. "The meaning of the terms limes and limitanei." Journal of Roman Studies 78: 125-47.

James, Simon. 2002. "Writing the legions: The development and future of Roman military studies in Britain." Archaeological Journal 159: 1-58.

Jones, A.H.M. 1964. The Later Roman Empire, 284-602: A Social, Economic and Administrative History. Oxford: Blackwell.

Kaegi, Walter E. 1965. "Arianism and the Byzantine army in Africa, 533-546." Traditio 21: 2353.

Kaegi, Walter E. 1981. Byzantine Military Unrest, 471-843: A New Interpretation. Amsterdam: A. M. Hakkert.

Kaegi, Walter E. 2003. Heraclius, Emperor of Bzyantium. Cambridge: Cambridge University Press.

Keppie, Lawrence. 1984. The Making of the Roman Army: From Republic to Empire. London: Batsford. 
Kissel, Theodor K. 1995. Untersuchungen zur Logistik des römischen Heeres in den Provinzen des griechischen Ostens (27 v. Chr.-235 n. Chr.). St. Katharinen: Scripta Mercaturae.

Łajtar, Adam. 2015. “Another Greek inscription from Novae (Lower Moesia) associated with pastus militum." In Ad Fines Imperii Romani. Studia Thaddaeo Sarnowski septuagenario ab amicis, collegis discipulisque dedicata, edited by Agnieszka Tomas, 277-88. Warsaw: Institute of Archaeology.

Lee, A. D. 1993. Information and Frontiers: Roman Foreign Relations in Late Antiquity. Cambridge: Cambridge University Press.

Lee, A. D. 2007a. War in the Late Antiquity: A Social History. Oxford: Blackwell.

Lee, A. D. 2007b. "Episcopal power and perils in the late sixth century: The case of Gregory of Antioch." In Wolf Liebeschuetz Reflected: Essays Presented by Colleagues, Friends and Pupils, edited by John Drinkwater and Benet Salway, 99-106. London: Institute of Classical Studies.

McCunn, Stuart. 2018. "Supply and Command: A Study of the Late Roman Commissariat." Unpublished PhD thesis, University of Nottingham.

McLynn, Neil. 2005. "Genere Hispanus: Theodosius, Spain and Nicene orthodoxy." In Hispania in Late Antiquity, edited by Kim Bowes and Michael Kulikowski, 77-120. Leiden: Brill.

McNeill, William H. 1982. The Pursuit of Power: Technology, Armed Force and Society since 1000. Chicago: University of Chicago Press.

Meier, Mischa. 2009. Anastasios I: Die Entstehung des byzaninischen Reich. Stuttgart: KlettCotta. 
Messer, William S. 1920. "Mutiny in the Roman army. The Republic." Classical Philology 15: 158-75.

Olster, David. 1993. The Politics of Usurpation in the Seventh Century: Rhetoric and Revolution in the Byzantium. Amsterdam: Hakkert.

Peddie, John. 1994. The Roman War Machine. Stroud: Sutton.

Petersen, Leif Inge Ree. 2013. Siege Warfare and Military Organizatiuon in the Successor States (400-800 AD). Leiden: Brill.

Potter, David S. 1990. Prophecy and History in the Crisis of the Roman Empire: A Historical Commentary on the Thirteenth Sibylline Oracle. Oxford: Clarendon Press.

Rizos, Efthymios. 2013. "Centres of the late Roman military supply network in the Balkans: A survey of horrea." Jahrbuch des Römisch-Germanischen Zentralmuseums 60: 659-96.

Rizos, Efthymios. 2015. "Remarks on the logistics and infrastructure of the annona militaris in eastern Mediterranean and Aegean areas." Antiquité tardive 23: 287-302.

Rodger, N.A.M. 1988. The Wooden World: An Anatomy of the Georgian Navy. London: Fontana.

Roth, Jonathan P. 1999. The Logistics of the Roman Army at War (264 BC-AD 235). Leiden: Brill.

Sarantis, Alexander. 2016. Justinian's Balkan Wars: Campaigning, Diplomacy and Development in Illyricum, Thrace and the Northern World, A.D. 527-65. Leeds: Francis Cairns.

Sarnowski, Tadeusz. 2005. “Drei spätkaizerzeitliche Statuenbasen aus Novae in Niedermösien." In Römische Städte und Festungen an der Donau: Akten den regionalen 
Konferenz, Beograd 16-19 Oktober 2003, edited by Miroslava Mirković, 223-30. Belgrade:

Filozofski Fakultet.

Sarris, Peter. 2006. Economy and Society in the Age of Justinian. Cambridge: Cambridge University Press.

Scharf, Rolf. 1991. "Praefecti praetorio vacantes: Generalquartiermeister des spätrömischen Heeres." Byzantinsche Forschungen 17: 223-33.

Stallibrass, Sue, and Thomas, Richard, editors. 2008. Feeding the Roman Army: The Archaeology of Production and Supply in NW Europe. Oxford: Oxbow.

Tougher, Shaun. 2007. Julian the Apostate. Edinburgh: Edinburgh University Press.

Tougher, Shaun. 2012. “Reading between the lines: Julian's First Panegyric on Constantius II." In Emperor and Author: The Writings of Julian the Apostate, edited by Nicholas BakerBrian and Shaun Tougher, 19-34. Swansea: Classical Press of Wales.

Whitby, Michael. 1988. The Emperor Maurice and his Historian: Theophylact Simocatta on Persian and Balkan Warfare. Oxford: Clarendon Press.

Whitby, Michael. 1995. "Recruitment in Roman armies from Justinian to Heraclius (ca. 565615)." In The Byzantine and Early Islamic Near East. III: States, Resources and Armies, edited by Averil Cameron, 61-124. Princeton: Darwin Press.

Wickham, Chris. 2005. Framing the Early Middle Ages: Europe and the Mediterranean, 400800. Oxford: Oxford University Press.

Wiedemann, T.E.J. 1996. "Tiberius to Nero." In The Cambridge Ancient History², vol.X: The Augustan Empire, $43 B C-A D$ 69, edited by Alan K. Bowman, Edward Champlin and Andrew Lintott, 198-255. Cambridge: Cambridge University Press. 
Wijnendaele, Jeroen. 2015. The Last of the Romans: Bonifatius - Warlord and comes Africae. London: Bloomsbury.

Williams, Stephen, and Friell, Gerard. 1994. Theodosius: The Empire at Bay. London: Batsford. 